\title{
The Transcendental Paradigm Of The Development Of Legal Law
}

\author{
Absori \\ The lecturer Doctoral Program of Muhammadiyah Surakarta University \\ absori@ums.ac.id \\ Sigit Sapto Nugroho \\ The lecturer Faculty of Law Merdeka Madiun University \\ sigit.nugroho26@gmail.com \\ DOI : https://doi.org/10.23917/jtl.v1i1.8786
}

\section{Submission}

Track:

Received:

10 May 2019

Final Revision:

20 June 2019

Available online:

29 June 2019

Corresponding

Author:

Absori

absori@ums.ac.id

Sigit Sapto Nugroho

sigit.nugroho26@gmail.com

\begin{abstract}
Purpose of the study: This article aims to formulate (1) epistemology jurisprudence has the positivistic level, (2) jurisprudence epistemology has transcendental paradigm, and (3) epistemology of the development of prophetic jurisprudence.
\end{abstract}

Methodology: This research uses library research by conducting research and data analysis and then they use it using knowledge, especially jurisprudence with transcendental values.

Main Findings: The base of epistemological positivistic jurisprudence that is objective, empirical and rational which are supported by systematic, procedural and formal models result in its development has lost essential elements, namely spiritual values, so that modern society has a crisis in defining the meaning of life in the world.

Applications of this study: The base of transcendental legal science understands people and their life in an intact form (holistic), not merely material nature but also their souls. The development of the prophetic law is intended as a guidance for human life to achieve happiness in the world and in the hereafter, because the prophetic law can not be fragmented between the physical body (formal) and transcendental values.

Novelty/Originality of this study: The paradigm of the transcendental epistemology of legal science emphasizes in the integration approaches between sciences and values in various views

Keywords: Development, Epistemology of legal science, Transcendental paradigm 


\section{INTRODUCTION}

The thoughts to seek alternative epistemology of jurisprudence in Indonesia keeps continuing in line with the development of the sciences. The aspiration to get moving on from the thoughts of modern positivism jurisprudence towards postmodernism jurisprudence starts to come to action in the world of law. Yearning for the peace of mind, inner soul, religious values and God becomes the powerful influencing factors. The consideration with the renewal paradigm towards that jurisprudence is what is meant as the post-positivism jurisprudence. The legal science of the post-positivism tries to perform different and distinctive concepts from the modern positivistic of legal science. It can be said that from time to time sciences undergo changes which are usually started from the changing of paradigm used. Postmodernism starts to deal with the things those are irrationals in nature (emotions, feelings, intuitions, personal experiences, speculations), moral and spiritual as an integral part to understanding scientific issues/research. The thoughts of law which are regarded as unsatisfactory (criticizing or rebelling) towards the liberal and steady modern paradigm jurisprudence is categorized as the postmodernism.

The fundamental reasons that the science in the modern world which are up to now considered to be able to solve everything, in fact, can not solve the problems of life and the life its self. The glory of science has come to an end (the end of science). Axiologically, science is no longer beneficial and it is considered as incapable to solve the problems in society. The science is dominantly regarded as having significant influences in all aspects of life but at the same time, it also has arisen many problems. In the world of modernism, transcendental perspective with all its aspects such as religions, ethics, and moral is put as a separate part from te unity of the development of the modern civilization. Because of that, modern science in its development has lost its essential element namely transcendental values. It happens as the effect of the way of thinking that is based upon the mundane life which is taken care of by the emperors and the religious matters are given to religious leaders (priests, monks, and ulemas). (Absori 2015).

In fact, actually in post-positivism, transcendental dimension can be seen in the wider angles in the form of religions, ethics, and moralities which are no longer understood in only one aspect, -the aspect which merely has something to do with theological and desires, but more than that, those problems can be put in dialogs with other development of scientific matters, social, economy and jurisprudence. 
The existence of the crisis in western society is regarded as the failure of the modern civilization caused by the modern thought which has separated spiritualism with all its aspects in the unity of life and the development of civilization of human beings. According to Suherman Djirman (a LIPI researcher) to understand the complex life and the civilization of human being, the science (thoughts) needs to be constructed. Spirituality is not just only intuition, modern science, in fact, can not reach spiritual dimension, because modern science relies on ratio which has analytical nature, logic, and systemic (Newtonian), while spiritual thought (ratio) is static (passive) and heart (the center of small world) is active, open to the complex universe (big world) is natural, emanating the depth of the inner meaning understanding life which are full of nature (Absori. 2015).

Though spirituality can not be understood by using the modern science but it can be felt. For that reason, it is important to understand science and the complexity of life by using spiritual quotient, so that it can build hopes from the spiritual light to reach the development of more holistic jurisprudence in the future so that it can be used as one of the solutions to solving the problems in jurisprudence. Based on the above explanations so the problems can be formulated as follows:

1. How does epistemology jurisprudence have the positivistic level?

2. How does jurisprudence epistemology have transcendental paradigm?

3. How is the epistemology of the development of prophetic jurisprudence?

\section{RESEARCH METHOD}

The writers use the literary study by doing research and the data analysis and then they are described using the integration among sciences, especially jurisprudence with the transcendental values.

\section{RESULT AND DISCUSION}

1. Epistemology of Jurisprudence is in level of Positivistic

According to Satjipto Raharjo in Sudjito (1014:4), the jurisprudence which develops in Indonesia nowadays tends to become practical science and not (not yet) as jurisprudence as a genuine science. It is said “... we have been trapped by the concept of "lawyer's law, "law for the lawyers" or "law for professional's....". It is a concept of law originated from the thoughts of the followers of positivism who only merely 
acknowledge the truth in practical levels, that is the reality which can be proven and can be accepted by the mind (logics). Jurisprudence as practical science works with normative texts called positive laws. It does not deal law as an intact reality but limited to the reality which is logical - rational only. It is identical with the thought of Newtonians who see the nature as a systematic building, mechanistic, linear, and deterministic, the positivists also demand that modern law is also rational, systematic, and logic.

Civil law system in Indonesian law system is an inevitable reality. The legal system inherited from the Dutch colonial legacy has been ingrained in the life of this nation. The core of the civil law system is rechtstaat, a concept in the legal thought that the governmental power is restricted by law. The thoughts of the civil law system give an emphasis on the legal certainty. Where the law can be used as an instrument that has the certainty to provide space and parameters which are obvious to the subjects of law, so the subjects of law will act in accordance with what has been stated, the judgment of the action of the subjects of law is formulated in the form of legislation (Arief Sidharta 2008: 124-125).

That idea shows that government legislation sees that the law is made into a positive in the form of a law or the formal law (state law), created through mechanical means so that the law is rational and systematic. The demands towards positivism of every legal norm historically done for the well-organized modern state life that guarantees legal certainty and freedom for every individual citizen.

In the paradigm of positivism, legal order is one of the social orders that supports the realization of a society that is more or less is in orderly. Based on Satjipto Rahardjo's view, a prominent feature of the legal order when it is compared with the other order (the order of customs and morality) is the creation of a law that is purely made deliberately by an entity established in the community which is made for it. In the process of its creation, it was supported by legal order norms deliberately and consciously made to establish a kind of norm that deliberately and consciously created to enforce a certain kind of order in society. The parties determining what kind of order it is none other than the people or their representatives appointed through a certain Mechanism. This community group then in the later has the legal authority to create law (Satjipto Rahardjo, 1996: 17). According to Hans Kelsen law deals with the form 
(formal), not the content (material). So justice as legal contents is outside the law. A law is therefore not fair, but it remains the law because it is made by the authority. Law is a must to regulate human behavior as rational beings (Satjipto Rahardjo, 1996: 242-246). As the opinion of Montesquieu quoted by Widodo Dwi Putro (2011: 1) that the paradigm of legal positivism, law or the whole legislation are thought as something that either contain the law fully so that the task of judges are to implement the provisions of the law mechanically and linearly to solve the problems of society, according to the law.

One of the characteristics of the modern laws is in terms of usage which are used actively and consciously to achieve certain goals. The consciousness causes the modern law to be very instrumental in nature. This life seemingly can be engineered with a law, and the doers are the elite. This is similar to the forest law where the law is only seen as an instrument to achieve its objectives. Viewed from the perspective of the strategy of development of the law, then up to this present time Indonesia, the implemented the development of repressive laws (repressive law) that are the positivist instrumentalist. In a repressive legal order, law as a servant of the repressive powers of a sovereign government (the carrier of political power) that has the unlimited authority. In this type, the law and the state and the law and politics are inseparable so that the instrumental aspect of the law is clearly observed on expressive aspects (Nonet Zelnik, 1978: 14-15).

The Strong evidence of the influence of legal positivism in the legal system of Indonesia is indicated by the willingness of unification and codification of the law, but in a pluralistic society, the law uniformity for sake of legal certainty would lead to resistance. To a certain extent, the plural society will reduce the domination of legal positivism, especially in the areas which are very close in contact with the culture.

Therefore ontologically in a pluralistic society, the meaning of the law in the sense of positive norms should become the major source thought it is not the only one. It means that in a pluralistic society to give a sense of justice, the judge is not only enough to be messengers of law, but he must open his ears widely and listen to the heartbeat of society before releasing the decision (Dwi Widodo Putro, 2011: 7).

In the level of empiric juridical, law enforcement is not only based on formal legal course, it means that there are laws of which life are based on local wisdom of indigenous peoples which are full of complexity, the diversity in Indonesia, in general, is a simple society that also lives and needs recognition.. Where the characteristics of a 
simple society, among others, can be seen from its legal structure that further highlight the role of customary norms. In such a simple society, the law is not only understood merely as normative texts which ought to be obeyed, observed and done but also as an integral part of the life of the entire society.

As said by Satjipto Rahardjo that the views of the progressive legal science in which legal science concerns with the pursuing of truth that requires complete picture, in the mean that the law is not only a form of order (order) but also irregularities (disorder) as also said by Sampford, which needs to be open to the reality of chaotic existence in law, because such circumstances could be really found in the law (Qodry Azizy, 2012: 14). Based on the above positivistic modern legal system that overrides the role of God, in the end, it leads to problems in the legal world that are sometimes difficult to solve, the human freedom with its reason and reality. Human life becomes dry and loses its meaning because modern positivistic science laws tend not to touch the level of spiritual inward.

2. The Development of Epistemology of Legal Sciences with the transcendental paradigm.

According to Bernard Arief Sidharta (2013: 71) as cited by Sigit Sapto Nugroho (2016: 99) the development of legal science in its scientific activities is departed from a number of assumptions and work within the particular general basic framework and enable the ongoing scientific activities and discourse (rational discussion and communication) within the scientific community of law. Thus, in the field of legal science paradigm, it is defined as a fundamental view of jurisprudence that should be studied and used with the scientific methods. There are a variety of paradigms as an approach to the development of science, such as positivism, post-positivism, holistic and transcendental (Absori, Kelik, Saeful, 2015: 33).

The views of transcendentals attract the attention of science initiators, it is regarded as a future alternative thought amid the positive dialectic rationalism which is considered not to be able to overcome various problems of life and living. The modern rational-positivistic science is not considered as everything. The transcendental thought with regard to the understanding that puts science in a wider range beyond the boundaries of rationalistic normative rules of science. Scientists put the transcendental 
study in the frame of science study which is metaphysical or supernatural because it exceeds the limits of physical and spiritual nature (Absori, 2017: 14-15).

The crisis of positivism paradigm built by the western world has shaken the confidence of man towards the civilization jurisprudence as a representation of intact reality. The crisis of paradigms has even led to new anxieties in the essence of nature of life, man's relationship with nature and man's relationship with the Creator. Starting from that anxiety, in turn it appears awareness to abandon the reductionistic and atomistic perspectives which are often synonymous with scientific methods, and in line with the needs to present the new paradigm as said by Fritjof Capra as quoted by Sudjito (2014: 10) that is holistic paradigm thought, so that the science of law can emerge as a true science (genuine science).

Another criticism of the philosophical and sociological towards the legal positivism school of thought has been put forward since its birth. For example, Charles Samport in his works Disorder of Law, which is actually legal positivism is a milestone in the recognition of legal certainty. In the realm of Das sollen, codification and unification of the law to ensure their textual certainty. However, in the level; of Das Sein, it was full of irregularities (disorder)and full of uniformity (disuniformity). Therefore, it is impossible to study law as a linear or single entity. Understanding of the law in an integrated and systemic system is a necessity that needs a critical review.

Why is systemic integrated approach needed? Charles Samport responds that legal certainty and regularity of legal law can not detach itself from the social relationship based on the power of relations between one institution to other institutions (power of relations). This view gets its place when Satjipto Rahardjo proposes a model of progressive legal approach.

Transcendental thinking can be seen in a wider range in the form of religion, ethics, and morality. Religion, ethics, and morality are no longer understood in one aspect, the aspects related to the issue of theology and the desire alone which can be seen through the doctrines and worship, but more than those, such issues of values can be discussed with the issue of scientific development, social, culture, economics, and law. Transcendental thinkers emphasize more to the values and meanings behind it, so it appears the building of science in a more open and intact in response to the matters of life and life. In this case, transcendental thoughts start lifting things that are irrational 
and metaphysics (emotions, feelings, intuition, values, personal experiences, speculation), moral, spiritual as part in understanding scientific (Absori, 2017: 15).

According to Satjipto Rahardjo with the spiritual intelligence approach, it can obtain the perfect (ultimate) intelligence, done in a way to bypass the lines of formalism (exciting rule) and transcendental so that it will obtain the new thought that is closer to the truth of the essentials (the ultimate truth). Where people require Spiritual Quotient which is a tool for people to be able to build a wider variety of new perspectives in life, and able to find the wider world horizons in its narrowness and can feel the presence of God without meeting with Him.

So far, the spiritual truth intentionally or unintentionally is avoided by scientists, because it is closely related to the study area of theology (religion). The question arises, why Allah revealed religion that teaches the true values of goodness and beauty. More complicatedly the inter-religious understanding and interpretation of a value are often different. This is perhaps the importance of discussion about religion or values, in order to find and connect the dots of similarities into the layout configuration value of muchneeded by human beings who crave tranquility and peace life.

Science can not remain silent to articulate the question of value, and should not assume that the problem is not considered as its region. Studies need to be encouraged to enter such areas and facilitating the contribution of excess (methodology) that, in order to make the convergence or the meeting point of the question of the truth of science and the vertical divine truth. This is our collective duty as a scientist.

Natural Islamic spiritual thought, for example, grew not out of the process of assimilation and acculturation between Islamic and Greek cultures. In the Qur'an itself, we can not find the word philosophy, because the Qur'an uses original Arabic, while philosophy is an Arabic word formation that has been affected by the philosophy of the Greeks. Philosophy of the science of nature, in the Qor'an is called with the words of wisdom or al-hikmah. Al-Quran contains a collection of writing about the revelation of God, while words wisdom or philosophy is the knowledge about the nature of things (Musya Asy'arie, 1992: 14).

According to Ali Ashraf as quoted by Turiman (2010: 23), science proceeding from moral values of the Qur'an and the Hadith, which are both do not only display the verses (proof of truth) but also hudan (policy guidelines), also rakhmah (grace of God). 
Because of that, the science does not just look for the truth that is based on reasoning and discourse but also look for policy, welfare, the blessing and mercy of Allah. In the Islamic perspective, science is axiologically is not just for science, but more than that, science should be helpful for the benefit and the interests of the people. Science exists in the life of human society and people are asked to use their potential, namely the mind and heart to understand it. In Islam, the intellect (al-aql) occupies a very important position, in addition to the qalb (the heart) and the other senses. Therefore the first revelation of God revealed through the Prophet Muhammad is Al-Alaq is known as the Iqra (read), mentioned in the Koran, "Recite in the name of your Lord who created", "Read and thy Lord is the most generous ". (Chapter Al-Alaq, verses 1 and 3).

With the potential they have, human beings are commanded to read the power of God in nature, as mentioned in the Qur'an "Verily in the creation of the heavens and the earth, and the alternation of night and day, there are signs for men of understanding" (QS Ali- Imran, verse 190)". And of His signs is the creation of the heavens and the earth and the diversity of your languages and your colors. Indeed in that are signs for those of knowledge"(Chapter Ar-Rum verse 22).

In Islam, the science can be extracted based on the Quran and Hadith and also there is Maslahat mursalah, which is a source of additional laws based on empirical research (istiqra), which is obtained from natural phenomena and the behavior of the people, it is found with the goal for the benefit of human life. It is based on the Koran which says "And We sent thee (prophet), but to be a grace for the universe" (Chapter Al-Anbiya, verse 107). The benefit can be captured clearly by those who have and want to think, even in Islamic views, there is a difference in understanding the nature of beneficiaries. That difference stems from the differences in intellectual ability of a person's in the interpretation of Islamic teachings contained in the Quran and hadith, in which each expert has limitations, so they are not able to understand the nature of beneficiaries in the same manner, due to the different temporal and regional conditions (local) which are not the same.

The spiritual dimension can be seen in the most basic teachings, the faith, which teaches the understanding of the relationship between humans and nature and with God. Man and nature are essentially mortal creatures, while God is the ruler of the universe and its contents (the Lord of the Worlds) is eternal (baqa). The greatest happiness of a 
Muslim is when he is able to surrender in totality to obey the commandments (laws) of Allah that are natural (sunnahtullah), both in general or detailed, as a consequence of his confession that Allah Almighty, ruler of all things, and all the creatures dependent on Him (QS.Al Ikhlas, 112: 1-2).

Spiritual perspective of science, including the science of law, is not only based on qauliyyah truth, which it is true at the level of haqq al-yakin, collected in the Qur'an and Hadith, but it is also based on the truth of the ability of human potential through uluum naqliyyah, ie, reflection, reasoning, and discourse developed in the community. Human beings explore the process and formulate science with the aim not only merely for science but also for the policy, the benefit of society at large, by the blessing and mercy of Allah.

We now live, as indicated by Fritjof Capra, as cited by Muhammad Ikhsan (2015) in a period of the turning point. Our inability to re-look at human life with a view as the whole, according to Capra, causing a crisis in the dimensions of Intellectual, moral, and spiritual of human beings. In human life, indeed the potential of mind and soul have encouraged people to seek, approach, and find the truth. There are some who are only able to approach and find the truth on the stage of superficial (formal truth), but some are not satisfied with the truth, they expect, seek, and find, or at least closer to the real truth, the material truth, substantial truth, absolute truth, ultimate truth, the divine truth, or whatever it's called.

The physical and mental levels of intelligence are further understood using scientific thinking, science according to an Imam al-Ghazali, a notable Islamic scientist, in his book entitled "Ihya 'Ulumiddin" and has been translated into Indonesian by Moh Zuhri (2003: 6-7). The Rationale of the researchers used the thought of Imam al-Ghazali in his book "Ihya "Ulumiddin" is a result of the continuously dialectic contemplation without stopping to devote the thoughts in order to find the idea of transcendental science paradigm which is believed to be able to answer the problems of law in Indonesia.

According to Imam al-Ghazali's ideas of human science were basically divided into two, namely "physical" and "inner / soul" sciences. The definition of physical science is the science in relation to the physical activities of parts of the bodies, while 
the inner/soul science is the science dealing with activities of the hearts and parts of the bodies which have something to do with good deeds whether indigenous or worship.

Many of the thoughts of Imam Al-Ghazali are taken from verses of al-Quran and al-Hadith which are related with the virtues of physical and mental science for humans, as contained in Surah Al 'Imran: 18 which means: "Allah bears witness that there is no God but he, who uphold justice. The angels and the people of knowledge (also stated that such) ". Qur'an has mentioned about the influence of physical and mental sciences for humans. With the knowledge they have, then God will give degrees of glory to humans, as contained in Chapter Al Mujadilah: 11 which means: "Surely Allah will exalt those who believe among you and those who were given some degree of knowledge".

\section{Epistemology of the development of Prophetic Legal Sciences}

According to Henddy Shri Ahimsa Putra (2011) the basis of transcendental dimension, Prophetic Law is depicted with the concept of humanization, liberation, and transcendence which is by Kuntowijoyo used in discussing the social sciences in general. In this case, the element of transcendence should be the basis of another element in the development of science and civilization. The methods of the development of science and religion which are known as prophetic are based on the Quran and the Sunnah and are the main base of the overall development of science. Prophetic which is pioneered by Kuntowijoyo resembles the concept of integration of science and religion by Amin Abdullah, according to the concept of Islamization of Naquib al-Attas and Ismail Raji al Faruqi. Prophetic later also became the paradigm of law in Indonesia. With the concept of humanization, liberation and transcendence legal sciences are built in order to find the epistemology of law that can address the problem of laws in Indonesia. Humanization is an attempt to take back the human dignity through the way of the Lord. Liberation is the science of law which has the prophetic responsibility to liberate humanity from the putridity. Transcendence is a form of law that contains the basic elements of faith in Allah (Khudzaifah Dimyati, 2014: 135-139).

According to Absori et al (2015: 396-397), the prophetic law sees the basic science as the instructions that are intuitive (faith) or a priori. Because of its intuitive nature so the knowledge begins from the ability of human receptive to what is 
transferred from the revelation or guidance, so prophetic paradigm rejects the view of doubts of uncertainty by Descartes or uncertainty by Derrida. In a prophetic paradigm, knowledge develops their relationship in human beings arising from the organs of understanding, including; senses (sense) either the inner or outer senses, inspiration or intuition located in the heart, ratio as a function of thinking and revelation to the prophet. The consequence of that things is the lack of prophetic integrity as an emancipatory consciousness: transcendence, humanization, liberation and historic activism: (a) the appreciation or engagement of thoughts and feelings on something that are believed (as the basis of all ethics / values); (B) servitude; (C) scientific work ethic; (D) humanitarian work ethic, which consists of: honesty; precision/ accuracy; critics and awards.

Kuntowijoyo interprets transcendent as the faith to Allah (Ali Imran:110), by introducing prophetic science, as humanization (ta'muruna bil ma'ruf), liberation (tanhauna anil munkar) and transcendental (tu'minuna billah). In this case, transcendental element should become the main of other elements in the development of sciences and human civilization. The method of science development and religion according to Kuntowijoyo is named as prophetic based on Al-Quran dan Sunnah which are the main base of all development of sciences. Al-Quran dan Sunnah are determined on the basis of the whole building of prophetic sciences, whether the science of nature (ayat Kauniyah) as the basis of the natural laws, humanism (ayat Nafsiyah) as the basis of meaning, values and the consciousness towards divinity (Ayat qouliyah) as the basis of the laws of God.

The understanding towards these things is headed to find the elements which are relevant to the development of sciences, supported by the science and understanding towards the philosophy of science. In the relationship with the human law as a subject and in the meantime as the bearer of trust to implement the divine laws which are definite and determined through the revelation (al-Qur'an) and the tradition of the prophethood sunnah or hadiths. Human beings can have a reorientation from thinking subjectively to thinking objectively, to have theory besides using normativity of teaching, change the understanding of a non-history to history and to formulate revelations which are general to be more specific and empiric. 
M. Amin Abdullah in the paradigm of connectivity tries to discuss between discipline and philosophical methodology and opinion which are known as the anthropocentric-integralistic, which tries to connect in integrate between opinion with various branches of sciences. M. Amien Abdullah introduces al-ta'wil al'ilmi to achieve the truth of science (law) using the approaches of bayani, irfani and buryani. Bayani works in the field of interpreting a text. The empiric reality is understood and interpreted based on texts. Irfani emphasizes on the experience through the emanation of the concrete truth (God), of which source is the deep inner mind experience, authentic, pure and unavoidable by logic. The validity of truth can be directly felt by other soul intuitions. Burhani emphasizes to the principal of the use of logic that bears the concrete conclusion and can be understood by logic.

M. Amin Abdullah adopts the ideas of Jasser Auda which state that Islamic laws can be developed as a methodology which unites between historical and philosophical approaches. The historical approach pays thoroughly to the changes and the movement of the concept, meaning, and interpretation of law in traditional, modern and postmodern eras. While the philosophical approach uses the system of theory which use to be used in science based on six features of cognition, wholeness, openness, interconnectedness, multi-dimensionality and always refers to the purposefulness.

The science in a transcendental view either can be observed based on Al-Quran and Hadith or in Maslahat Mursalah, which becomes an additional source of law based on an empirical research which is achieved from natural phenomena and the behavior of the society, found with the purpose to achieve the welfare of the people's life. Those things are based on the Al-Qur'an which says "And [thus, O Prophet,] We have sent thee as [an evidence of Our] grace towards all the worlds". (QS Al-Anbiya, ayat 107). The benefit can be caught clearly by the people who have the willingness to think, though in the Islamic perspectives there are differences to understand the true meaning of beneficiaries. Those differences start from the difference of the intellectual abilities of the people in interpreting Islamic teachings in AL-Quran and Hadith, where the scholars have their own limitations so that they can not understand the true usefulness altogether, because of the difference in nature which is temporal and local condition which are not same. 
Transcendental dimension can be observed from the very basic teachings, namely aqidah which teaches to the understanding of the relationship among human beings with nature and God. Human beings and nature are the creations which are fana (immortal) while God is the conqueror of the universe who is eternal. The best happiness for Moslems is when they are able to completely surrendering themselves to obey the laws of Allah which are definite (sunnatullah), whether they are general or rigid, as their consequences to their admittances to Allah, The One and Only, the conqueror of everything, and all creatures depend on Him.

Prophetic laws are rooted to the will of Allah towards his creatures which are revealed through the prophets and Messengers of God, the scholars, and aulia who are constantly bound and tightly hold the parts of divine teaching (sunatullah). Sunatullah is the basis of natural law which is described through His verses which are written in AlQur'an and Hadiths or those which are described in the universe and the reality fo life. The prophetic law is proposed as the way of life of human beings to obtain the happiness in the world and hereafter. The prophetic law can only be understood using the holistic approach which sees the human beings and their life in a united form, it is not material but immaterial. The prophetic law can not split between physical body (formal) and transcendental values.

So the justification of the development of legal science with transcendental paradigm can only be understood with the holistic approach which sees the human beings and their life in a whole figure, not only in a material form but also ruhaniyah (immaterial). The transcendental legal law can not be split between a physical figure (formal) and transcendental values. Justification of transcendental legal law only which are searched in the sake of justice based on the will of Allah, the Almighty, the determiner of the life and the life of the human beings as the manifestation of the affection to His creations.

\section{CONCLUSION}

First, the base of the positivistic epistemology of the science of law is objective, empirical and rational and supported by the systematic, procedural and formal models. Departing from the journey of Indonesian history up now that, there are shades of contradictory typology scientific understanding of the law, which is a form of mismatch 
between the scientific understanding of the law in terms of the level of physical terms supported by positivistic understanding of legal science in the sense that the level of inner mind supported by post-positivistic. Those incompatibilities can be described as an imbalance between the physical and inner mind of human beings. So the result and impact in the world of law are an understanding that is not whole and incomplete or far from perfection.Secondly, there is a strong tendency to understand the science of law not only in terms of normative positivists, but more than that, the science of law must be seen in the form of the whole orders. The transcendental science of law paradigm emphasizes the integration approach between science and values in various forms and views. In this case, the science of transcendental law can only be understood in a holistic approach that sees humans and their life in an intact form, not merely material nature but ruhaniyah (immaterial). Human explores, processes and formulates science with the aim not only as the science but also as the policy, the benefit of society at large, by the blessing and mercy of Allah.

The third, prophetic laws are rooted from the will of Allah towards His creations which are revealed through His prophets and messengers, the scholars and aulia who are always steady (istiqomah) and hold tightly to the divine ways (sunnatullah). The prophetic law is proposed as the way of life of human beings to reach the happiness in the world and hereafter. So prophetic law can not separate between physical figure (formal) and transcendental values. So the justification of prophetic law is searching for the sake of justice which is based on the truth of Allah and its orientations are towards the usefulness of the human being as the form of His affection.

\section{REFERENCES}

Absori, 2015, Epistimologi Ilmu Hukum Transendental dan implementasinya dalam Pengembangan Program Doktor Ilmu Hukum, Prosiding Seminar Nasional di Universitas Muhammadiyah Surakarta.

, 2017, Pemikiran Transendental dalam Konteks pengembangan Ilmu Hukum Indonesia, dalam Proseding Transendensi Hukum : Prospek dan Implentasi, Program Doktor Ilmu Hukum Sekolah Pascasarjana Universitas Muhammadiyah Surakarta.

Absori, Kelik Wardiono, Saepul Raochman, 2015, Hukum Profetik, Kritik terhadap Paradigma Hukum Non-Sistematik, Genta Publising, Yogyakarta. 
Arief Sidharta, 2008, Apakah Filsafat dan Filsafat Ilmu Itu, Pustaka Sutra, Bandung

Bernard Arief Sidharta, 2013, Ilmu Hukum Indonesia: Upaya Pengembangan Ilmu Hukum Sistematik yang Responsif Terhadap Perubahan Masyarakat, Genta Publising, Yogyakarta.

Henddy Shri Ahimsa Putra, 2011, Paradikma Profetik, Mungkinkah, Perlukah, Makalah, UGM, Yogyakarta.

Imam Al-Ghazali, 2003, Ihya' Ulumiddin: terjemahan oleh Moh. Zuhri, Semarang, Asy Syifa.

Khudzaifiah Dimyati, 2014, Pemikiran Hukum: Kontruksi Epistimologis Berbasis Budaya Hukum Indonesia, Genta Publishing, Yogyakarta.

Nonet, Philip dan Zelznik, Philip, 1978, Law and Society in Transition : Toward Resonsive Law, New York, Harper \& Raw

Muhammad Ikhsan, 2015, Epistemologi Mencari Kebenaran dengan Pendekatan Filsafat Transenden, Proceding Seminar, Universitas Muhammadiyah Surakarta.

Musya Asy'arie, 1992, Filsafat islam suatu Tinjauan Ontologis, dalam Filsafat Islam suatu Tinjauan Ontologis, Epistemologis, Aksiologis, Historis dan Prospektif, Lembaga Studi Filsafat Islam, Yogyakarta.

Qodry Azizy dkk, 2012, Menggagas Hukum Progresif di Indonesia, Pustaka Pelajar kerjasama dengan IAIN Walisongo dan Program Doktor Undip Semarang.

Satjipto Rahardjo, 1996, Ilmu Hukum, Alumni Bandung.

Sigit Sapto Nugroho, Pengembangan Epistemologi Ilmu Hukum berbasis Transendental, Jurnal Perspektif, volume XXI No.2 2016 Edisi Mei.

Sudjito, 2014, Ilmu Hukum Holistik, Gajah Mada University Press.

Turiman, 2010, Memahami Hukum Progresif Satjipto Rahardjo dalam Paradigma Thawaf, Undip, Semarang.

Widodo Dwi Putro, 2011, Kritik Terhadap Paradigma Positivisme Hukum, Genta Publising, Yogyakarta

"Dan tiadalah Kami mengutus kamu (Nabi), melainkan untuk menjadi rakhmat bagi alam semesta" (QS Al-Anbiya, ayat 107). 